\title{
MONOTHEISM AND ITS POLITICAL CONSEQUENCES
}

\author{
fan Assmann
}

\section{The 'Mosaic Distinction' and the Problem of Violence}

Monotheism introduced a new distinction into the realm of religion, bringing about a totally new form of religion whose hallmark was less the exclusive worship of one god, but the distinction as such. This distinction implies a whole scale of concretizations between the poles of a more ontological and cognitive meaning with regard to true and false, and of a more ethical and 'deontic' meaning with regard to 'good' and 'evil,' or 'just' and 'unjust,' or 'freedom' and 'slavery.' Drawing the distinction entails making a decision, and this decision of necessity implies rejecting the discarded option. This new form of religion is based on a decision, which in its turn is based on a deep conviction, implying strong notions of what is deemed incompatible. All convictions aspiring to any depth and power require those strong concepts of the excluded other. The monotheistic, or 'Mosaic' distinction, which in its last consequence means the distinction between 'God' and 'the world,' is hard to draw, and the Bible is very explicit about these many difficulties and drawbacks. ${ }^{1}$ Monotheism required a firm decision and correspondingly strong concepts about 'the other,' for which a whole new vocabulary was created: the 'heathens,' 'pagans,' 'gentiles,' 'unbelievers,' 'idolaters,' 'heretics' etc. The strength of the decision and the firmness of the conviction imply an element of violence. This element of violence becomes obvious as soon as the distinction between true and false or good and evil is turned into the distinction between 'friend' and 'foe.' I do not hold that this new form of religion brought violence into the world; the world, of course, was already full of violence before the advent of monotheism. One could even argue that monotheism, by abolishing ethnic and national distinctions and creating overarching identities and solidarities, tends to make the world more peaceful. But it is impossible to deny that - at least potentially - this

${ }^{\prime}$ Assmann (1996, 1997, 2003). 
kind of religion implies a new type of violence, religiously motivated and directed against those who, in the light of that new distinction, appear to be the enemies of god.

'Enemies of God,' however, sounds familiar not only in the context of monotheism, but also in the context of 'pagan' religion. It is a normal device in ancient Egyptian and Mesopotamian sources to represent the political enemy as an enemy of God. In order to get a clearer view of the problematic alliance between religion and violence, we must distinguish between 'interpretation' and 'motivation.' The religious interpretation or legitimation of violence is as old as warfare in general. Examples stretch from the Ancient Near East to the most recent military activities in East and West. What is new, is the religious motivation of violence the idea of killing a person or starting a war for the sake of God, to fulfill his will and orders, acting as God's executioners.

This new type of religion is based on a truth or a 'law' - that requires the resolution either to kill or to die for it, a new form of 'religious heroism,' which implies either active or passive intolerance. On what could be called the 'mythical' plane, the plane of the founding stories and grand narratives modeling the lives of peoples and individuals, active intolerance is exercised, e.g., by Moses after the episode of the Golden Calf, when 3000 men "brothers, friends, neighbors" were killed; by Pinhas, who killed his kinsman Zimri together with a Midianite girl in the act of love-making, ${ }^{2}$ by Joshua and the whole complex of the "conquest"; by Elijah killing the priests of Ba'al after winning the contest, ${ }^{3}$ etc. The list is much longer, and though these events belong to myth and not to history, it seems to me highly significant that the new religion attaches so much importance to violence in its narrative self-presentation. Violence belongs to what could be called the 'core-semantics' of monotheism. I do not state that monotheism is violent; merely that it dwells on scenes of violence in narrating its path to general realization.

On the plane of history, active intolerance was shown by Josiah destroying the "high places" (bamot) and killing the priests; ${ }^{4}$ by Ezra divorcing the mixed marriages; ${ }^{5}$ and above all by Judas Maccabaeus,

\footnotetext{
Num 25:7.

$1 \mathrm{Kg} \mathrm{18:40.}$

$2 \mathrm{Kg} 23$.

Ezra 9: 1-4.
} 
who applied the fictitious and archaic Deuteronomist regulations concerning the Canaanite towns, which "must not be spared"6 to the Jewish towns and communities that abandoned the way of the Law and succumbed to Hellenism. To those towns, "the ban was executed" and every living being was killed. ${ }^{7}$ In I Maccabees, the story is told with pride, not with horror. The biblical term for active intolerance is qana, "zeal." God is a "zealous god" (El qana), persecuting the idolatry of the fathers down to the third and fourth generations, and those who love him are expected to be equally zealous in fighting for the Law. Monotheism requires a zealous attitude; it is a virtue to be zealous, i.e. to engage totally in the cause of God. The Arabic equivalent, of course, is djihad. The Maccabaean wars seem to be the first religiously motivated wars in history. They were wars of resistance, to be sure, led in defense against an aggressor and his project of forced assimilation.

Judging from numerous discussions, modern theologians - Jews and Christians, Catholics and Protestants - hate to be reminded of these biblical stories and react violently to this line of reasoning, which they decry as "anti-Semitic." They point to the unhistorical, purely fictional character of these texts, as if this would solve the problem. It is precisely the fictional or rather mythical character of most of these stories which makes them potentially dangerous. I am not talking about 'history,' but about cultural semantics conditioning and motivating the actions and attitudes of peoples living in the horizon of these semantics. I consider it dangerous to close one's eyes vis-à-vis the potentially negative or malignant implications of one's convictions. In a global world we cannot afford such an apologetic attitude. Stark denial is not helpful; reflection is required. I do not want just to criticize or reproach monotheism's violent implications, but to encourage a process of reflection and, if possible, what in Freudian terms is called "sublimation." I do not advocate abolishing the Mosaic distinction, but rather call for more reflective, considerate and historically informed ways of dealing with it.

Active intolerance, however, is only one side of what I have called 'religious heroism.' The other side is passive intolerance, i.e. martyrdom, in Hebrew qiddush ha-shem. On the plane of myth, this form

\footnotetext{
${ }^{6}$ Dtn 7:2: lo tekhanem, cf. 13:16f. and especially 20: 16-18.

71 Macc 5.
} 
of qana - "zeal for the Lord" - appears in the Book of Daniel, ${ }^{8}$ which was written in the time of the Maccabaean Wars; on the plane of history, it appears during these same wars in the form of heroic resistance to Antiochus IV Epiphanes' project to turn his kingdom into the first 'nation-state' in human history, a state where there should be only one people, one religion and (what was regarded to be the same) one law. ${ }^{9}$ Many Jews resisted this forced assimilation and preferred to die rather than bow to an idol or eat sacrificial meat, becoming by this form of zealous engagement for the Law the first martyrs in history. Also in this context, it has to be stressed that there are many examples of heroism and of 'dying for' outside the horizon of monotheism. Roman history especially is full of examples of heroic Romans who preferred death to ignominy, slavery or other privations they considered incompatible with their convictions about 'Romanhood,' honor, patriotism, and bravery. Martyrdom, however, i.e. to die for God, was something new, and it was based on this same distinction between true and false or good and evil, which is the hallmark of the new religion. Drawing the distinction, forming the decision, rejecting the excluded option to the point of dying rather than giving in and compromising: this is the line that leads from a new form of religious conviction to its personal, social and political consequences.

Both, active and passive intolerance, are interpreted and justified in the Bible as a kind of 'fulfillment': the fulfillment of scripture. This idea of 'scripture' is equally novel and innovative. Two kinds of written texts may be identified, which I propose to term 'informative' and 'performative.' Informative texts require our attention; performative texts, our obedience i.e. fulfillment, execution, or translation into action and behavior. Informative texts tell us something important or amusing about the world; performative texts order and prohibit, and in doing so make claims of our life. Holy writ is a performative text: it requires that it be performed or fulfilled in our way of living. This hold true for, at least, the Jewish or, to be more precise, the 'halakhic' concept of scripture, which, however, is also present in various forms in the other monotheistic religions. All monotheistic religions, even Buddhism (which, though not monotheistic, is still a religion based on a variant of the Mosaic distinction),

${ }^{8}$ Ch. 3, ch. 14.

${ }^{9}$ I Macc 1:41-64. 
imply performative scripture in the form of canons of holy writ, determining the forms of personal, social and political action and behavior in the way a film script determines the actions and speeches of the actors. Martyrdom is the form of acting out a performative text in which this relation between scripture and fulfillment becomes most clear. The Jewish martyrs typically die with a verse of scripture on their lips. Death is the most radical and the most decisive way of fulfilling, acting out, or living out scripture; not in the temple, the sanctuary or some other sacred place, but in everyday life and in the most profane and unholy situations and places. ${ }^{10}$

Again we must realize that the world was already full of scripts, performative texts prescribing human action and claiming strict obedience and fulfillment, well before the emergence of monotheism. These texts, however, never claimed to regulate the whole of human life, but only certain spheres of action, as may be regulated either by law codes and royal edicts or by rituals and ceremonial prescriptions. The Torah, it is true, contains many similar laws and prescriptions, and there are many singular parallels in other ancient civilizations, but there is no parallel for the claim the Torah holds on the totality of human existence, nor for the divine origin and timeless, absolute validity of such an all-encompassing regulation. Without this form of performative scripture, the underlying distinction, decision and conviction cannot be maintained and reproduced through the sequence of generations and radical changes of context and circumstances history brings about in the course of centuries. The Mosaic distinction requires and brings about a thorough restructuring of cultural memory. This form of living in the horizon of a canon is not exclusively Jewish; in various permutations, it applies to many minoritarian communities in antiquity. They left the mainstream ways of life in favor of alternative, purer paths, typically based and gathered around a core-library of normative and 'performative' scripture: the Pythagoraeans, the Orphics, the Platonists and other philosophical schools, the 'sectarian movements' in early Judaism, the various branches of Gnosticism and Hermeticism, the Christians, the Buddhists, the Manichaeans, the Mandeans and others. In all these movements, we meet with the desire for the sanctification of life, for living a life in fulfillment of a sacred or sanctioned script, a life in truth and goodness.

${ }^{10}$ See Agus (1988). 
Drawing the distinction and making the decision requires a firm mind and heart. Monotheism implies not only a new idea of god but also, and above all, a new concept of man, laying much stress especially on 'inner man' (ho endos anthropos in the words of St. Paul, interior homo in those of Augustine). Israel is required not only to recognize god's unity (aechad), but love the Lord "with all thy soul, all thy heart, all thy power". ${ }^{11}$ The development of new forms of inner life, of subjectivity, reflectivity and inner conflicts, is among the most important personal consequences of monotheism. Conversion and repentance are perhaps the most prominent and the most innovative of these new forms of inner life. Also in this respect, I would dare the thesis that conversion and repentance are unthinkable concepts in the context of traditional 'pagan' religions. These religions could not be separated from culture and society. You could assimilate to Egyptian or Mesopotamian culture, but never 'convert' to the respective religions. Conversion implies a decision based on the Mosaic distinction between true (or good, or just) and false (or bad, or unjust) religion. Conversion means making a decision about the true forms of life and belief. Repentance - teschuvah in Hebrew, metanoia in Greek - means a total transformation or reformation of one's ways of living. It is closely connected to a concept of sin which is equally revolutionary. Making mistakes and repenting of them afterwards is, of course, a universal phenomenon. I am thinking of an existential turn, caused by an awareness of the general sinfulness of one's former life. I am not speaking of specific misdeeds, but of the fundamental and existential sinfulness of the 'natural state,' i.e. a life outside the Law, unheeding the will of God, as it is expressed, e.g. in Ps 51 v. 7 :

for I am born in guilt,

in sin my mother has conceived me.

and in verse 19:

Das Opfer, das Gott gefällt, ist ein zerknirschter Geist, ein zerbrochenes und zerschlagenes Herz wirst Du, Gott, nicht verschmähen.

The god of monotheism has no divine partners, his partner is man; both in the shape of the chosen people, Israel, and that of the indi-

1 See the 'schema prayer', Dtn 6.5. 
vidual Israelite, who assumed, in this new kind of religion, a totally new dignity. The individual now found himself or herself confronted with god, even exposed and surrendered to god's omniscience and critical attention. Monotheism is a drama between god and man, acted out on the arena of, both, everyday life and of the inner life of the psyche. The 'I' of the psalms stands firstly for a singular suffering or jubilating, imploring or thanksgiving individual, secondly for everybody confronting his god in similar situations, and thirdly for the community of Israel. It is an 'I' 'larger-than-life,' accommodating all three meanings in its exposed position before God. Monotheism means an extension of the traditional world in the direction of transcendence and subjectivity, or outer and inner transcendence.

This new form of intensified subjectivity finds its clearest expressions in the sentiment of repentance and the step of conversion, to leave one's former life which one has come to recognize as wrong, sinful or evil, and to enter the life of truth, the way of the Law or the imitation of Christ. All this is totally alien to 'pagan' religions. Repentance and conversions are dramatic plays acted out on the inner stage of the human heart, which co-evolved with the monotheistic turn in ancient Israel.

\section{The Political Consequences of Monotheism}

The 'monotheistic turn' means both a revolution and an evolution, stretching over many centuries and including many drawbacks and movements in the opposite direction. The law of evolution reads "Natura non facit saltus," and it applies also to cultural history. But culture does make leaps, not perhaps in actual history, but in history as it is perceived, remembered and represented. The monotheistic turn is represented in the Bible as a revolutionary 'leap' of the highest possible degree. The prolonged sojourn of Israel in Egypt for more than four centuries effaces every memory of the patriarchal past in Canaan, and the exodus from Egypt cuts the links to the host culture and helps to prepare a 'tabula rasa' for God on which to write His revelation. Moses means a new beginning and the installation of a new religion, turning an amorphous mass of nameless emigrants into the 'Chosen People,' the people of God. The revelation of the Law at Mt. Sinai constitutes the 'primal scene' of monotheism. 
This primal scene is politically determined in such a way as to suggest that monotheism is originally a political religion, in the sense of a sacralized political movement. I am envisaging, to be sure, the event at Mt. Sinai in its broader context, including the exodus from Egypt, the wanderings through the wilderness and the conquest of the Promised Land, and I am interpreting this narrative complex not in the sense of real history, but of mnemo-history. This means that I am asking for the form in which monotheism remembers and tells the story of its origins. The primarily political character of this story is obvious. The story is about liberation from Egyptian serfdom, a purely political action, in clear opposition to a kind of political order and organization, for which Egypt stands as its symbolical exponent. This political action leads to the constitution of the Hebrews as the people of God and a "kingdom of priests and a holy people" (mamlekhet kohanim we-goj qadosh), ${ }^{12}$ an alternative political organization and the political antithesis to the oriental empires, based on the principle of sacral kingship or 'representative theocracy.' The form of this constitution is a treaty, a political alliance between the people and God.

Monotheism is the basic principle and the first commandment of this new political order: "I am YHWH thy God that has liberated thee from Egypt. Thou shalt not have other gods beside me." This does not mean that there are no other gods, but that Israel should not have other gods. This makes a big difference. Israel is committed to political loyalty, to staying loyal to the alliance and not breaking away to other overlords. Loyalty is a meaningful concept only if there are other gods. Exclusivism, the hallmark of monotheism, is therefore originally a political concept, meaning the exclusivity of allegiance to one particular god, not the exclusive existence of one god only. It concerns the alliance between the people of god and the god of liberation. To the loyalty of Israel corresponds the "jealousy' of God: both are political properties. Both, loyalty and jealousy, are political concepts. Only with the transformation of a sacralized political movement into a new form of full-fledged religion, the exclusivity of God turns from a question of commitment into a question of existence.

The Schema prayer, it is true, being a central part of the Sinai revelation, states that YHWH is 'ONE,' aechad. This may be inter-

${ }^{12} \operatorname{Ex~19:6.}$ 
preted both ways: in the sense of an exclusivity of commitment, which befits the following injunction to love YHWH "with all thy heart, all thy soul and all thy might," but also in the sense of absolute oneness or unity. In this context, the other gods that Israel is requested not to 'have' are not only forbidden, but nonexistent, false, fictive gods. Monolatry turns into Monotheism. YHWH is the only true god. The tension between monolatry and monotheism, loyalty to the one in full recognition of the existence of other gods on the one hand, and the recognition of only one god denying the existence of other gods as mere idols on the other hand, this tension marks biblical religion from the beginning. The borderline between the one god YHWH and the other gods is originally a political boundary, separating the Chosen People from the rest of the nations, but it tends right from the start to take on the cognitive or 'existential' meaning between true and false gods.

This border, the distinction between true and false or good and evil with regard to religion is the proper innovation of monotheism. This distinction simply did not exist previously in the realm of religion. There were foreign religions with foreign, unknown gods, but nobody would have declared these gods false and fictitious or wrong and evil. Not the oneness of god, but the concept of 'idols' is the real monotheistic innovation. There were no idols and heathen in the realm of tribal religion and polytheism. The construction of paganism is the single achievement of monotheism, based on the distinction between true and false.

Monotheism, therefore, is a religion that blurs boundaries, the boundaries that are expressed or represented by the divinities of polytheism: between cities and countries, tribes and nations, day and night, land and sea, love and war, good and evil - but that also erects a boundary: between true and false, religion and idolatry. Monotheism is, at the same time, exclusive and universalistic. Both tendencies, the exclusive and the universalistic, have political consequences.

The political problem of universalism consists in its lack of legitimizing function. The chief gods of polytheistic religions are state gods and represent political unity. Ashur stands for Assyria, Marduk for Babylonia, Amun-Re for Egypt, Athena for Athens etc. In this way, YHWH originally stood for Israel but the biblical god soon outgrew this political role. Pure monotheism does not recognize national gods. This problem is solved by the monotheistic religions in different ways. The Jewish solution consists in 'sub-sovereignty.' 
Israel develops the pure form of monotheism only under minority conditions, in the Babylonian exile and under Persian rule. Under these conditions, YHWH may renounce his political function as a state god and become truly universal. The Christian and Islamic solution of this problem is the empire. So little monotheism suits the needs of a national religion, so well it functions as an imperial religion. It does not support a nation-state, but an empire. Christianity is linked to the Roman Empire, Islam forms empires of its own, from the Abassid, Omayyad, Fatimid etc. up to the Ottoman empires.

Nineteenth and twentieth century nationalism, therefore, represented a mortal danger to the alliance between religion and politics, in the Muslim East as well as the Christian West. The typical nationstate is a secular state. This holds for post-revolutionary France, as well as for Turkey, Syria, Iraq, Egypt and even early Zionism. Nationalism is also a political religion that does not tolerate other religions beside itself. Religious nation-states such as Pakistan and Iran are exceptional and problematic constructions. The same would apply to a not yet existing 'Serbia' (at least not under this designation), with its national branch of Greek orthodox faith. The political forms that are congenial to monotheistic universalism are either minority conditions or imperial multinationalism.

But there is also the political problem of the 'Mosaic distinction' with its construction and exclusion of paganism. The political consequences of this distinction turn dangerous only if it is interpreted in terms of friend and foe. Then, the idolaters turn into enemies of God and the political leaders turn into God's willing executioners. This interpretation seems typical of the political world view of the two extreme spearheads, of radical Islamism and the Bush administration. One side speaks of Allah's enemies, the other of the axis of evil. Each side perceives the other as the providential foe, the "personification of its own question" ("ihre eigene Frage als Gestalt"):

Der Feind ist unsre Frage als Gestalt, und er wird uns, wir ihn zum selben Ende hetzen.

The foe personifies our own question and he will hunt us, we him, down to the same end.

Whereas Carl Schmitt saw in these verses by Theodor Däubler the epitome of the political, I would understand them as expressing a pathology of politics, a malign clinch calling for therapy. The polarization of the political world into friend and foe seems in itself patho- 
logical, but it becomes mortally dangerous if the foe is demonized far beyond his real possibilities and intentions for destruction. In those cases the point is reached where politics merges with myth and religion.

\section{Monotheism, Violence and the Modern Situation}

Twenty years ago, the global situation was still determined by the Cold War, i.e. the confrontation between two powers, one of which, the communist block, considered itself as atheistic, and the other, the capitalist block, as Christian. It appears that religion was only involved on the one side of this confrontation, the capitalist side. The opposite, in fact, is true. The communist totalitarianism of the Soviet empire presented the paradigmatic case of a political religion, i.e. politics with a religious, even messianic perspective aiming at establishing a paradise on earth in form of class-free society and eternal peace. Communism was not connected to a religion, but was in itself a religion. Using Shmuel N. Eisenstadt's important distinction, we may say that it is deeply rooted in, but not caused by, Christian and Jewish millennialism. There is certainly no evolutionary trend leading from Christian or Jewish religion, or even Gnosticism, to Marxism; still, these religions laid the foundation for a new religion, or anti-religion, to arise. Being an universal or 'world-religion' in itself, it did not tolerate another religion beside itself. Soviet Communism was a religion and even what I call a "secondary or counter-religion," 13 including a church and an orthodoxy, because it was based on the distinction between true and false and had codified this distinction in a canon of holy writ, including the works of Marx and Engels, Lenin, Stalin and Mao. It demanded belief and propagated the polarization of believers and pagans, capitalism thereby playing the role of paganism. ${ }^{14}$

Capitalism, on the other hand, is not a religion, in the same way as paganism is not a religion, but just a polemical and external classification. As a religion, communism had no real counterpart in the West. The exact counterpart was only represented by Islam. If

13 Assmann (1997).

${ }^{14}$ Gellner (1994: 170-181). 
towards the heathen, Christianity is a globalizing and polarizing, i.e. politicizing, religion.

Yet even Judaism implies a globalizing tendency. It is not missionary, but lives among the peoples. What mission is to Christianity, diaspora is to Judaism. Judaism, originally a religion of self-exclusion from the orbit of other peoples, destined to live as a 'Chosen People' in the 'Promised Land,' had to live dispersed among the peoples in a form of passive globalization.

If Christianity is a globalizing religion intending to spread over the whole earth, it is nonetheless about a reign which is not of 'this world.' The Augustinian distinction between the City of God and the City of Man is constitutive of Christian thought and practice, although it had often been deliberately blurred. Mission does not necessarily mean subjugation, though in history both quite often went together. Islam, however, does not know of such restrictions. The pagans are neither excluded nor violently 'missionized,' but subjugated and converted. Here, the distinction reads Dar el Islam and Dar el Harb: "house of Islam" and "house of war". This means exactly: 'where there is no Islam, there is war.' And since war is not a desirable state, the rule is: 'where there is war, shall be Islam.' For this reason, Islam is the most pronouncedly globalizing religion among the three Abrahamitic monotheisms. The globalizing element of monotheism is present only in a passive form in Judaism, in the form of diaspora; it becomes active in Christianity, but tempered by a that-worldly orientation; and finds its intemperate political expression only in Islam.

The globalizing dynamics of monotheism is based from in its underlying universalism. If there is only one god, $\mathrm{He}$ is responsible for all countries and peoples. Polytheism expresses the diversity and plurality of the world, monotheism knows of only one god, one world and one humanity. For this reason, the Bible interprets the diversity of languages as a punishment and a 'depravation of creation.' The plurality of peoples, goyim in Hebrew, acquires the negative meaning of 'pagans,' and in the Arab expression dar el-harb, this negative meaning becomes most manifest. The three monotheisms handle their universalistic perspective, however, in very different manner. Judaism postpones it to a 'messianic age.' History is determined by the plurality of the nations and religions. Only at the end of time, in the post-histoire of messianic time, will the peoples convert to the One God and go to Zion for worship. 
For Christianity, the Messiah has already come, bringing, however, not the end of history; the end will come only when the gospel has been told to all the peoples. Until then, the kingdom of God is in a certain mysterious way present, it is 'true,' but not of this world. At least the shi'ite Islam knows of this messianic-eschatological postponement, but not of the Christian dichotomy of the two kingdoms. Islam insists on realization, that is, on transformation of religion into politics here and now; it leaves no doubt that its kingdom is of this world. Of the three Abrahamitic religions, it is the one that is most resolute in the realization of the political implications of monotheistic universalism.

This most unequivocally and politically globalizing religion sees itself now confronted with a similarly globalizing movement, not in Christianity, but in the shape of post-Christian secularism, which shares with Christianity its universalistic impulse but not its spiritual perspective and which, for the same reason, globalizes the world in such a successful and even irresistible way that it can only be perceived by Islam as a mortal threat. With Western secularism on the one side and Islam on the other, we have two religions which operate on the political plane with the claim to universal power, and which demonize each other as mortal enemies. In this extreme status, however, this analysis holds true only for the two extreme spearheads of these two powers, Islamism and fundamentalism on the one hand and the Bush administration as the exponent of Western values or value-fundamentalism (democracy, individualism, market economy etc.) on the other. This offers to the more moderate zones within and between the two blocks, to liberal Islam and to pluralistic Europe with its partly Islamic history, the chance of playing the role of the third and of breaking up the dangerous dualism.

Is it possible or even probable that the radical polarization of the world is connected with the Mosaic distinction between true and false religion? I would think so, but its destructive potential is only realized in a modern, post-monotheistic world. In this situation, the only cure seems to consist in a resolute de-demonization of the other. The West should beware of demonizing Islam by confounding it with Islamism (and then depicting it as the 'personification of its own question'). Islam is a complex and pluralistic phenomenon. The West should support the liberal, reformist trends as opposed to the fundamentalists and puritans (the Wahhabites) with their radical fanaticism. Of crucial import is also the disentanglement of politics and 
religion. Western secularism must not see and advertise itself as the only true and universal form of political order. Islam or Islamism, in turn, should no longer insist on the immediate political realization of its religious norms and notions.

Monotheistic religion must remember its original critical impulse. It was originally intended as a means of breaking up the inseparable unity of 'rule' and 'salvation,' 'Herrschaft' und 'Heil,' typical of the representative theocracies of the Eastern empires, Babylonia, Assyria, Egypt, Persia and Hellenism ruled by gods and the sons of Gods. The idea of the 'covenant' burst the compact unity of rule and salvation and withdrew salvation from the hand of the rulers. Monotheism originally meant political criticism. Biblical monotheism opposed the pharaonic oppression with its utopia of a decent society, where nobody was enslaved or humiliated. Monotheism meant the definition of an Archimedean point, from which to unhinge the political orders of the ancient world. This issue may be defined as the separation of religion and politics. This separation is given up where religion foregoes its critical potential and establishes a new form of totalitarian unity, forcing politics, jurisprudence, art and other cultural fields under its vision.

The political theology of the Pentateuch and the prophets has a double direction. It is not only about founding and legitimating a new form of political order, but it is also and primarily about criticizing and delegitimizing the traditional prevailing order; and this, not the foundational function, is the most important aspect of biblical political theology. Biblical monotheism as it appears in the Books of Exodus and Deuteronomy is a weapon directed against the political structures of the Ancient Near East. However, if we continue reading in the Hebrew Bible beyond the Pentateuch, from the Books of Judges and Samuel to the Books of Kings and further through the Books of the Prophets, it becomes crystal clear that biblical political theology is not so much directed against Egypt and Babylonia, but it rather addresses Israel's own society. Egypt and Babylonia are just symbols for what is considered to be wrong in terms of political order. Moses standing before Pharaoh is just a model for the later prophets to confront their respective kings in Jerusalem, Samaria and Babylon. Biblical Monotheism constructs a new platform from which to criticize and delegitimize political order. This platform simply did not exist in the pre-Israelite world. Religion was part of the system. 
Now, it became a system of its own, separated from culture including politics, economics, arts and sciences.

Yet, the function of biblical political theology is, both, critical and foundational; it delegitimizes the previous political order and legitimizes a new one. It separates religion from the rest of culture, but it tends to transform the whole of culture in the light of truth. It differentiates and it de-differentiates. As a means of differentiation, it represents an immense achievement in the history of mankind, in terms of freedom and human rights against the claims of politics; as a power of de-differentiation, however, of totalitarian 'Gleichschaltung' (ideological standardization and synchronisation) of culture under the dictate of religion, it is a danger to human freedom.

For a close, I would like to summarize my interpretation of monotheism as being (originally) a political movement of resistance and liberation in five points, which correspond to five leitmotifs in the Biblical narrative:

(1) The motif of liberation. The liberation from Egyptian serfdom is the first and foremost foundation of the new religion; it is thus purely political, meant to found human society on a new basis which forever precludes oppression, exploitation and humiliation.

(2) The motif of God's oneness, uniqueness or solitude. As we have seen, this has also, at least originally, a political meaning. Political alliances are exclusive: you must serve two overlords. A small state such as Israel was constantly confronted with the decision of whether to side either with Egypt or Assyria, but never with both. The only way to escape these constraints was to form an equally exclusive alliance with God that excluded other gods and other lords. The resolution to recognize only one God is, by its origin, a purely political intention.

(3) The motif of God as legislator. A legislating god was unknown to the world of polytheism. God as judge, to be sure, was a central concept in Egypt and Mesopotamia, but legislation was the task of the king. The idea of justice was divine, but the formulation and promulgation of concrete laws to be derived from the idea of justice was the task of the king, because the laws were deemed to be dependent on historically changing situations. The legislating god replaces the king in his most important function.

(4) The motif of the wrath of God. The jealousy and the wrath of God are political affects, distinguishing the sovereign ruler. The 
biblical god develops these qualities only after the formation of the covenant at Mt. Sinai. Unlike the gods of Egypt and Mesopotamia, YHWH does not rule over other gods, but over human people, and assumes the necessary political emotions in relation to his people.

(5) The prohibition of images. Many things arouse the anger of God, but he reacts most furiously to images. The primal scene of the wrath of God is the story of the Golden Calf, which God resents as defection to other gods. What is wrong with images? Images are the medium through which the gods of ancient polytheisms exerted their rulership on earth. The ancient oriental state may be classified as a 'representative theocracy.' The states were ruled by state-gods, Assur in Assyria, Marduk in Babylonia, Amun-Re in Egypt, yet they ruled not directly but indirectly, through representatives such as the king, the sacred animals and the innumerable images in the temples. Mundane government is just a replica and representation of divine rulership, and draws its legitimacy from this 'theo-mimesis.' This sphere of representation is destroyed by the prohibition of images. The god of Israel rules directly, not indirectly. Every image would destroy the immediacy of His presence. The covenant is based on direct theocracy. In this context, I would also like to refer to Shmuel N. Eisenstadt's remark on Augustine's rejection of any representation of the city of God on earth. According to Eisenstadt's understanding of Augustine's position, people could not 'represent' the City of God without conceiving themselves as divine. In this rejection of representation, Eisenstadt detected what he called an "Axial theme," a feature of "axiality." Axial Age civilizations develop a strong aversion to representing the divine, because it implies the danger of self-deification. There is first a Jewish, then a protestant reserve against political institutions representing the divine on earth, such as les rois thaumaturges in France and also some elements of sacral kingship in pre-reformation England. This is the political meaning of idolatry; and, in my view, it belongs to the original semantic core of monotheism.

\section{REFERENCES}

Agus, Aharon (1988). The Binding of Isaac and Messiah. Albany, NY: University of New York Press.

Assmann, Jan (1996). "The Mosaic Distinction: Israel, Egypt, and the Invention of Paganism." In: Representations 56: 48-67. 
. (1997). Moses the Egyptian. The Memory of Egypt in Western Monotheism. Cambridge, MA: Harvard University Press.

. (2003). Die Mosaische Unterscheidung oder der Preis des Monotheismus. Munich: Hanser.

Gellner, Ernest (1994). Encounters with Nationalism. Oxford: Blackwell.

Gentile, Emilio (2000). "The Sacralization of Politics: Definitions, Interpretations and Reflections on the Question of Secular Religion and Totalitarianism." In: Totalitarian Movements and Political Religions 1, 1: 34-55.

Meddeb, Abdelwahab (2002). La maladie de l'Islam. Paris. Seuil. 